\title{
A latex fixation test using British latex and bovine gamma globulin
}

\author{
R. B. PAYNE \\ From the Department of Pathology, Welsh National School of Medicine, Cardiff
}

SYNOPSIS A British polystyrene latex-bovine gamma globulin fixation test which can be used for serum titrations is described. It is technically easier to perform than the latex fixation test of Singer and Plotz (1956) and appears to be equally sensitive. There was agreement with a sensitized sheep cell agglutination test in 264 of 300 cases $(88 \%)$.

The agglutination of a suspension of polystyrene particles of uniform size mixed with a solution of human gamma globulin in an alkaline buffer by serum from patients with rheumatoid arthritis was first described by Singer and Plotz (1956). Rheins, McCoy, Buehler, and Burrell (1957) showed that gamma globulin from seven animal species, including the cow, could be used in place of human gamma globulin. Burby and Behr (1958) used the American polystyrene latex manufactured by the Dow Chemical Co. ${ }^{1}$ to show that human and bovine gamma globulin gave complete agreement in fixation tests on 26 positive and 34 negative sera.

The American latex has only recently become readily available in Britain but a similar, less expensive suspension has been manufactured by Styrene Products Ltd. ${ }^{2}$ Burby and Behr (1959) reported that the British product gave the same results as the American in latex-bovine gamma globulin tests if used in a different dilution, but Coke (1959) found they they agglutinated spontaneously. He used this reaction as the basis of a latex agglutination inhibition test. Agglutination was inhibited by the serum of most patients with arthritis not of rheumatoid type, but not by the serum of most patients with rheumatoid arthritis. The test cannot be used for serum titrations because agglutination occurs in the test system in the absence of serum.

By analogy with antigen-antibody reactions it seemed possible that spontaneous agglutination could be inhibited by excess of either latex or bovine gamma globulin. A non-agglutinating mixture could be used for serum titrations if its reactivity were retained.

Received for publication 4 October 1960

'Distributed by Difco Laboratories

2Distributed by British Drug Houses, Ltd.

\section{PRELIMINARY INVESTIGATIONS}

Borate-saline buffer $p \mathrm{H} 8 \cdot 2$ (Singer, 1958) and a stock suspension of British latex (Burby and Behr, 1959) at a final concentration in the test systems of 1 volume in 100 volumes were used in the preliminary investigations (see Appendix). Unless otherwise stated the reactants were mixed in $2 \frac{1}{2}$ in. $\times \frac{1}{2}$ in. tubes, heated in a water-bath at $56^{\circ} \mathrm{C}$. for two hours, and the presence or absence of agglutination determined with the naked eye after allowing the tubes to stand at room temperature for 18 hours by holding them in a strong oblique light against a dark background.

Mixtures of a constant concentration of latex and a wide range of concentrations of bovine gamma globulin were tested in this way. The results are shown in Table I.

Agglutination did not occur with bovine gamma globulin concentrations above $3 \cdot 1 \times 10^{-1} \mathrm{~g} . / 100 \mathrm{ml}$. and below $4.9 \times 10^{-5} \mathrm{~g} . / 100 \mathrm{ml}$. Agglutination was also absent between concentrations of $6.3 \times 10^{-3}$ g. $/ 100 \mathrm{ml}$. and $7.8 \times 10^{-4} \mathrm{~g} . / 100 \mathrm{ml}$.

Serial dilutions in glycine-saline buffer of sera from patients with rheumatoid arthritis and from normal controls were mixed with equal volumes of various British latex-bovine gamma globulin so that the test systems contained final concentrations of latex and bovine gamma globulin which had been shown not to agglutinate in the absence of serum.

Agglutination failed to occur with any rheumatoid serum tested. At bovine gamma globulin concentrations of $6.3 \times 10^{-1} \mathrm{~g} . / 100 \mathrm{ml}$. and above. At concentrations between $6.3 \times 10^{-3} \mathrm{~g} . / 100 \mathrm{ml}$. and $7.8 \times 10^{-4} \mathrm{~g} . / 100 \mathrm{ml}$. it was possible to obtain titres with a clear end-point. Prozoning did not occur. At concentrations below $4.9 \times 10^{-5} \mathrm{~g} . / 100 \mathrm{ml}$. a titre 
TABLE I

REACTION BETWEEN BOVINE GAMMA GLOBULIN (B.G.G.) AND A CONSTANT CONCENTRATION OF LATEX

\begin{tabular}{|c|c|}
\hline B.G.G. Concentration $(\mathrm{g} . / 100 \mathrm{ml})$. & Reaction \\
\hline $2 \cdot 5$ & Nil \\
\hline $1 \cdot 3$ & , \\
\hline $6.3 \times 10^{-1}$ & $"$ \\
\hline $3.1 \times 10^{-1}$ & Ägglutination \\
\hline $1.6 \times 10^{-1}$ & , \\
\hline $7.8 \times 10^{-2}$ & $"$ \\
\hline $5.0 \times 10^{-2}$ & $"$ \\
\hline $3.9 \times 10^{-2}$ & ", \\
\hline $2.5 \times 10^{-2}$ & $"$ \\
\hline $2.0 \times 10^{-2}$ & $"$ \\
\hline $1.3 \times 10^{-2}$ & $"$ \\
\hline $9.8 \times 10^{-3}$ & ", \\
\hline $6.3 \times 10^{-3}$ & Nil \\
\hline $4.9 \times 10^{-3}$ & , \\
\hline $3.1 \times 10^{-3}$ & $"$ \\
\hline $2.4 \times 10^{-3}$ & $"$ \\
\hline $1.6 \times 10^{-3}$ & $"$ \\
\hline $1.2 \times 10^{-3}$ & $"$ \\
\hline $7.8 \times 10^{-4}$ & " \\
\hline $3.9 \times 10^{-4}$ & Agglutination \\
\hline $2.0 \times 10^{-4}$ & , \\
\hline $9.8 \times 10^{-5}$ & $"$ \\
\hline $4.9 \times 10^{-5}$ & $"$ \\
\hline $2.4 \times 10^{-5}$ & Nil \\
\hline $1.2 \times 10^{-5}$ & , \\
\hline $6.1 \times 10^{-6}$ & $"$ \\
\hline All lower concentrations tested & 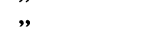 \\
\hline
\end{tabular}

could be obtained but there was a prozone with many of the positive sera tested. The prozone became more marked and the titre became lower as the bovine gamma globulin concentration was reduced. A final concentration of bovine gamma globulin in the test system of $5 \mathrm{mg} . / 100 \mathrm{ml}$. gave the highest titres with the majority of the positive sera tested and was selected for use.

The titres obtained using the technique of Burby and Behr (1958 and 1959), but using a final concentration of bovine gamma globulin of $5 \mathrm{mg}$./100 $\mathrm{ml}$. instead of $25 \mathrm{mg} . / 100 \mathrm{ml}$., were compared with the titres obtained after heating the reactants as follows:

1 Unheated latex suspension and bovine gamma globulin solution were mixed and added to unheated positive sera and to sera heated to $56^{\circ} \mathrm{C}$. for one hour:

2 Latex suspension and bovine gamma globuli solution were heated separately to $56^{\circ} \mathrm{C}$. for one hour, cooled and added to heated and unheated serfo

3 Latex suspension and bovine gamma globuli solution were mixed, heated to $56^{\circ} \mathrm{C}$. for one hou and for two hours and added to unheated sera ang to sera which had been heated to $56^{\circ} \mathrm{C}$. for one houf? both undiluted and in serial dilutions in buffer.

The highest titres were obtained when the latex bovine gamma globulin mixture was heated to $56^{\circ} \mathrm{W}$ for two hours, cooled, and added to the serurtis dilutions. Heating the sera undiluted or in serial dilutions in buffer did not alter the titres.

On the basis of these results a latex fixation test with British latex and bovine gamma globulin which can be used for serum titrations has been devised. $b$ has been compared with a sensitized sheep cefl agglutination test.

\section{METHODS}

The latex fixation test is described in full in the Appendix. The sensitized sheep cell agglutination test was that 8 Greenbury (1957), with the exception that all sera we absorbed for two hours once only with washed unsep sitized sheep cells (after Ball, 1950). Occasionally absorn tion was incomplete. A differential agglutination tit was then calculated (Rose, Ragan, Pearce, and Lipman 1948). The tests were performed in plastic agglutinatio trays. Sheep serum was not used.

The two tests were performed on sera referred fe्ष Rose-Waaler tests within 48 hours of each other and usually on the same day. The latex fixation tests were read by the author and the sensitized sheep cell agglutina tion tests were read independently by Dr. J. L. With of this department. Neither was aware of the clinicat diagnoses at the time of reading.

\section{RESULTS}

The titres obtained in the two tests on 300 sera a shown in Table Il.

TABLE II

TITRES IN LATEX AGGLUTINATION AND SENSITIZED SHEEP CELL AGGLUTINATION TESTS IN 300 CASES

Latex Titre Sensitized Sheep Cell Agglutination Test Titre

\begin{tabular}{|c|c|c|c|c|c|c|c|c|c|}
\hline & \\
\hline & $<16$ & 16 & 32 & 64 & 128 & 256 & 512 & 1,024 & 2,0 舟 \\
\hline 5,120 & - & - & - & - & - & - & 1 & 1 & סדים \\
\hline $\begin{array}{r}2,560 \\
\end{array}$ & - & - & - & 7 & $\overline{2}$ & 1 & 1 & $\begin{array}{l}1 \\
4\end{array}$ & 2 \\
\hline $\begin{array}{r}1,280 \\
640\end{array}$ & $\overline{2}$ & $\overline{1}$ & $\begin{array}{l}1 \\
3\end{array}$ & $\begin{array}{l}1 \\
8\end{array}$ & 2 & 1 & $\overline{2}$ & 4 & 15 \\
\hline $\begin{array}{l}640 \\
320\end{array}$ & 4 & 1 & 3 & $\begin{array}{l}0 \\
5\end{array}$ & 4 & 2 & 3 & $\overline{2}$ & \\
\hline 160 & 5 & 2 & - & 1 & 4 & 3 & 2 & - & 2 \\
\hline 80 & 7 & - & - & 5 & 2 & 1 & 1 & - & 1 \\
\hline 40 & 7 & 1 & - & 1 & 1 & 1 & - & - & $\rightarrow$ \\
\hline 20 & 7 & 2 & - & - & 1 & 2 & $\bar{z}$ & $=$ & ב \\
\hline $\begin{array}{r}10 \\
<10\end{array}$ & $\begin{array}{r}18 \\
143\end{array}$ & $\overline{5}$ & $\overline{4}$ & $\overline{1}$ & $\overline{2}$ & $\overline{1}$ & $=$ & $\overline{-}$ & $\vec{z}$ \\
\hline$<10$ & 143 & 5 & 4 & 1 & & & & & \\
\hline
\end{tabular}


The reading of the end-point in the latex fixation test showed good reproducibility when repeated 'blind' by one observer. Variation between observers was very rarely more than one dilution. Variation between repeated tests on the same serum was never more than one dilution.

In the sensitized sheep cell agglutination test agglutination at an initial serum dilution of 1 in 32 or greater was considered positive.

Conventionally the latex fixation test is considered positive if agglutination occurs at an initial serum dilution of 1 in 20 or greater. Table III shows the

TABLE II I

COMPARISON OF 300 DUPLICATE TESTS

Latex Test

Sensitized Sheep Cell Agglutination Test

\begin{tabular}{lcc} 
& Positive & Negative \\
\hline Positive $^{1}$ & 87 & 39 \\
Negative & 8 & 166
\end{tabular}

${ }^{1}$ Latex fixation 1 in 20 or greater positive.

correlation between the tests using these criteria. There is agreement in $84.3 \%$ of cases.

It will be seen that the latex test is nearly always positive when the sensitized sheep cell agglutination test is positive and is often positive when the latter is negative. This might be due to greater sensitivity of the latex test or to false positive reactions.

It would be convenient to reduce the sensitivity of the latex test as closely as possible to that of the sensitized sheep cell agglutination test. This can be done by assuming the latex test to be positive at an initial serum dilution of 1 in 80 or greater. Table IV

\section{TABLE IV}

COMPARISON OF 300 DUPLICATE TESTS

\begin{tabular}{lcc} 
& \multicolumn{2}{c}{ Sensitized Sheep Cell Agglutination Test } \\
\cline { 2 - 3 } & Positive & Negative \\
\hline Positive $^{1}$ & 82 & 22 \\
Negative & 14 & 182 \\
&
\end{tabular}

shows the correlation between the tests using these criteria. There is agreement in 264 of 300 tests $(88 \%)$.

An attempt has been made to analyse the clinical conditions of the patients whose sera have given different results by the two tests. This has been done by reference to the clinical diagnoses given on the request forms and, where necessary, by discussion with the clinicians.

Of the 14 cases in Table IV positive by the sensitized sheep cell agglutination test but negative by the latex test, 11 were cases of definite or probable rheumatoid arthritis. The remaining three patients had no arthritis but were coalworkers with chest radiographs considered by Dr. A. Caplan to be typical or suggestive of rheumatoid pneumoconiosis (Caplan, 1953). Of the 22 cases positive by the latex test but negative by the sensitized sheep cell agglutination test, 17 were cases of definite or probable rheumatoid arthritis, two were coalworkers without arthritis but with chest radiological appearances suggestive of rheumatoid pneumoconiosis, and three cases remain undiagnosed. Of these, one is thought to have polyarteritis, one is thought to have systemic lupus erythematosus, and the third, a boy of 13, had a transient polyarthritis of undetermined origin.

\section{DISCUSSION}

The reactions between various concentrations of bovine gamma globulin and a constant concentra-

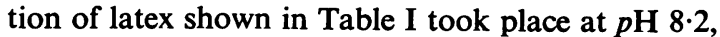
well above the isoelectric point of bovine gamma globulin. It is therefore unlikely that the agglutination which occurred was due to insolubility of the protein. There is good evidence that polystyrene particles are 'coated' by globulins. If bovine gamma globulin molecules and polystyrene particles are polyvalent in their mutual affinity, partially coated particles would be expected to interact and agglutinate. No observable reaction would be expected in the presence of excess of either. In fact, agglutination occurred at many concentrations between $6.3 \times 10^{-1}$ g. $/ 100 \mathrm{ml}$. and $2.4 \times 10^{-5} \mathrm{~g} . / 100 \mathrm{ml}$, , and no reaction was observed at higher and lower concentrations. However, it has not been possible to find a simple explanation for the absence of agglutination at bovine gamma globulin concentrations between $6.3 \times 10^{-3} \mathrm{~g} . / 100 \mathrm{ml}$. and $7.8 \times 10^{-4} \mathrm{~g} . / 100 \mathrm{ml}$.

Greenbury (1960) has shown that his modification of the Rose-Waaler test (Greenbury, 1957) gives a very high positive rate in rheumatoid arthritis and a low proportion of false positives, and therefore forms a suitable base with which to compare the efficiency of other tests. The titres obtained with Greenbury's modification of the sensitized sheep cell agglutination test in the present series showed no correlation with the titres obtained with the British latex-bovine gamma globulin test. A lack of correlation of titres has been reported by others using American latex and human gamma globulin as the reagents, for example, Steinberg, Roberts, and Lock (1959). Greenbury compared his test with the original latex fixation test of Singer and Plotz (1956). Sera 
were tested at a single dilution of 1 in 20 only. He found agreement in 2,893 of 3,222 tests $(89.8 \%)$. There was agreement in 264 of 300 tests $(88 \%)$ in the present series, suggesting that the British latexbovine gamma globulin test is approximately as sensitive as the American latex-human gamma globulin test.

The advantages of the technique presented in the Appendix are that, instead of incubating all the tubes containing serum dilutions at $56^{\circ} \mathrm{C}$. for two hours as in the original method of Singer and Plotz (1956), it is necessary to incubate only a mixture of latex and bovine gamma globulin in bulk, and centrifuging is unnecessary. The reagents are easily obtainable and cost less than $3 \mathrm{~s}$. for the titration of 100 sera. Prozoning has not occurred with any of the sera tested.

I wish to thank Dr. J. L. Withey for reading the sheep cell agglutination tests, for permitting me to use sera referred to him, and for his interest and helpful advice.

\section{REFERENCES}

Ball, J. (1950). Lancet, 2, 520.

Burby, G., and Behr, G. (1958). Ibid, 2, 1157
Burby, G., and Behr, G. (1959). lbid., 1, 1209.

Caplan, \&. (1953). Thorax, 8, 29.

Coke, H. (1959). Ann. rheum. Dis., 18, 301.

Greenbury, C. L. (1957). Broadsheet No. 18 (New Series), The Rose Waaler Test. Association of Clinical Pathologists, London. (1960). J. clin. Path., 13, 325

Rheins, M. S., McCoy, F. W., Buehler, E. V., and Burrell, R. G] (1957). Proc. Soc. exp. Biol. (N.Y.), 96, 67.

Rose, H. M., Ragan, C., Pearce, E., and Lipman, M. O. $(1948 \$$ Ibid, 68, 1.

Singer, J. M. (1958). Summary of First Conference on Serologickn Reactions of Rheumatoid Arthritis, p. 56. Arthritis and Rheumatism Foundation, New York.

- , and Plotz, C. M. (1956). Amer. J. Med., 21, 888.

Steinberg, V. L., Roberts, P. D., and Lock, S. P. (1959). J. clīi Path., 12, 448.

\section{ADDENDUM}

Since this paper was submitted for publication the test described has been compared with the RA-tesP (Hyland) which uses human gamma globulin as tho reactant. Of sera from 141 subjects, 53 were positive and 82 negative by both tests. Two sera were positiv at a titre of 1 in 80 in the latex-B.G.G. test and four sera were weakly reactive in the RA-test but negative in the other test. There was agreement in 135 of the 141 cases $(95 \cdot 7 \%)$.

\section{APPENDIX}

\section{REAGENTS}

GLYCINE-SALINE BUFFER $p \mathrm{H} \quad 8 \cdot 2$ An 0.1 M glycine solution is adjusted to $p \mathrm{H} \mathbf{8 . 2}$ by the addition of $\mathrm{N}$ sodium hydroxide, and $10 \mathrm{~g}$. of sodium chloride added to each litre.

The buffer may be stored at 2 to $4^{\circ} \mathrm{C}$. for several months, but must be discarded if turbidity develops.

STOCK GAMMA GLOBULIN SOLUTION An $0.1 \%$ solution of Armour bovine gamma globulin fraction II in buffer.

The gamma globulin solution may be stored at $-20^{\circ} \mathrm{C}$. for several months, preferably in separate small quantities to avoid repeated thawing and freezing.

STOCK LATEX One volume of B.D.H. polystyrene latex ( $30 \%$ suspension) is added to 50 volumes of distilled water and filtered through a Whatman No. 40 filter paper. The density is adjusted by the addition of distilled water so that when 1 volume of stock latex is added to 10 volumes of buffer the dilute latex gives a light transmission of 33 to $35 \%$ in a $1 \mathrm{~cm}$. cell at $650 \mu$.

The stock latex may be stored at 2 to $4^{\circ} \mathrm{C}$. for several months but must be discarded if clumps develop.

\section{METHOD}

A latex-globulin mixture is made by mixing 2 volumes of stock latex with 93 volumes of buffer and adding 5 volumes of stock gamma globulin solution. Ten millilitres of this mixture is required for each serum. Sufficient mixture for the sera to be tested is placed in a suitable stoppered container, heated in a water-bath at $56^{\circ} \mathrm{C}$. for two hours and allowed to cool.

The sera are diluted serially in buffer from 1 in 40 to 1 in 20,480 in clean $\frac{1}{2}$ in. $\times 2 \frac{1}{2}$ in. tubes and $1 \mathrm{ml}$. is lete in each tube. Control tubes containing $1 \mathrm{ml}$. of buffe only are also prepared.

One millilitre of heated and cooled latex-globuliog mixture is added to each tube.

Readings are made after the tubes have stood at room temperature for 18 hours.

Agglutination of minor degree is most easily seen by holding the tube in a strong oblique light and inspecting it against a dark background. A hand lens is not usee. Agglutination is present if there is complete sedimentatiof of the latex particles or if discrete particles can be seen in suspension. Agglutination is absent if the suspensiog remains uniformly milky, even if a small amount of sediment is present.

The titre of a serum is the greatest initial serum dilution showing agglutination. Agglutination at $\overrightarrow{\mathrm{a}}$ dilution of 1 in 80 or greater is considered a positive test. The control tubes should show no agglutination. $\frac{\mathbb{D}}{\mathbb{Q}}$ 